\title{
„КАД СУ ЦВЕТАЛЕ ТИКВЕ” - ДРАМА И ПОЗОРИШНЕ АДАПТАЦИЈЕ У ИСТОРИЈИ РЕЦЕПЦИЈЕ
}

\begin{abstract}
У раду се рецепција Михиловићеве драме Кад су цьветале тикве сагледава у спрези са друштвено-историјским контекстом и политичком позадином која прати њено објављивање и позоришна извођења. Критичка рецепција дела доводи се у везу са свеукупним културно-историјским дијалогом читалаца са текстом, са указивањем на утицаје које спољне околности имају на формирање индивидуалних и колективних читалачких доживљаја, као и различита тумачења и вредновање поменутог текста. Рад даје преглед специфичне „уметничке егзистенције“ драмске верзије Тикава, уз осврт на шири културни контекст и подељени критички одјек драме, који је заслужан за контроверзни статус који Михаиловићева дела имају чак и у данашњем, актуелном тренутку.
\end{abstract}

Кључне речи: драматизација, рецепција, културно-историјски контекст, позоришно извођење, субверзивност, критика.

1. КА КУЛТУРОЛОШКОМ чИТАњУ ТЕКСТОВА. Друга Половина двадесетог века је књижевнокритичкој мисли у науци о књижевности пружила подстицај за вишеструко иновирање утврђених научних метода, чиме се домен истраживања шири и помера ка мултидисциплинарном испитивању динамичних веза између књижевности и културног контекста у којем она настаје, али и у којем се прима, односно, реципира. На тај начин, нови модел науке о књижевности у себе интегрише бројна постигнућа различитих хуманистичких наука, богатећи своју истраживачку стратегију разноврсним перспективама и приступима који истражују један континуирани дијалог између књижевности и контекста (друштвеног, историјског, политичког, културног).

Насупрот некадашњој доминацији текстоцентричних приступа и усмерености на формалне аспекте књижевних дела, савремена наука о књижевности

\footnotetext{
${ }^{1}$ tinaksentijevic@yahoo.com
} 
одбацује илузију о вакууму естетске аутономије текста, бежи од пуког формализма и преиспитује широк спектар проблема који се тичу узајамних односа текста и друштвене стварности. Тај однос, међутим, треба сагледати вишесмерно: сазнања књижевности и културе јесу производи једног симултаног подухвата тумачења и међусобно се прожимају и подстичу. Смер савремених књижевних истраживања због тога иде, како у правцу од друштвеног ка свету текста, тако и од света текста ка друштвеном феномену. Класична теорија књижевности тако у постмодерном добу улази у једну интегралну, хуманистичку културолошку методу, која отвара своје истраживачко поље према непосредној друштвеној и идеолошкој пракси, богатећи се новим импликацијама и водећи рачуна о сложености свих аспеката једне уметничке творевине.

Обновљена свест о друштвеној и историјској димензији дела, која је данас присутна у готово свим водећим књижевно-научним теоријама, водила је радикалној истраживачкој преоријентацији ка читаоцу, а тиме и ка проучавању процеса рецепције. Савремена књижевна истраживања обележена су упечатљивим превратом: фокус проучавања се у књижевним теоријама помера са аутора и дела, на читаоца и сам начин на који се одређено дело прима и сазнаје. Низ теорија које се појављују шездесетих година двадесетог века (теорија рецепције, критика читалачког одговора, реторичка критика и др.) дају свој допринос проучавању читалачке улоге и њеног удела у тумачењу и конститиуисању значења књижевних творевина. Прималачком акту је, дакле, почетком двадесетог века дат значајан простор, да би у његовој другој половини постао доминантно питање књижевно-научног дискурса, разнолико манифестовано у теоријским радовима Романа Ингардена, Волфганга Изера, Ханса Роберта Јауса, Стенлија Фиша и др.

С читаоцем, као активном друштвено-историјском категоријом, отвара се могућност праћења дела у његовом стварном животу и постојању кроз историју, али и сагледавања историје књижевности као живог, дијалектичког процеса примања и деловања дела у различитим друштвено-историјским ситуацијама. Естетику дела, дакле, замењује естетика примања и деловањ $a$, тј. естетика заснована на пракси књижевног живота и друштвене димензије књижевности. Отуда, Јаусовим терминима речено, историја књижевности представља изазов науци о књижевности, јер у себе нужно укључује и историју рецепције и деловања одређене књижевне творевине у актуелној друштвеној стварности. Модерна струјања у наратолошким дисциплинама такође су окренута стратегијама читања, разумевања и тумачења текста, што је водило ка дубљем истраживању рецепције у њеним когнитивним основама. Померање фокуса посткласичних наратолошких истраживања на домен читалачке когниције и менталног процесуирања наратива изнедриће низ наратолошких дисциплина којима је феномен рецепције кључно теоријско исходиште: афективну, реторичку, природну, когнитивну наратологију итд. 
Спрегу књижевности и културне праксе у којој она настаје најпотпуније истражује новоисторијска оријентација, која се афирмише 80-их година двадесетог века, вођена Стивеном Гринблатом као њеним зачетником. Нови историзам се инспирише најпре „Деридином револуцијом”, која показује прва неповерења у језик као поуздано оруђе сазнања; Фукоовим теоријама о дискурсу као дисциплинирајућем фактору целокупне културне и стваралачке праксе; Вајтовим ставовима о текстуализованом приступу историји, као и антрополошким истраживањима Клифорда Герца. Вођени овим утицајима, новоисторичари укидају дотадашњу маргинализацију контекста и почињу да говоре о књижевности која је истовремено социјално продукована и социјално продуктивна. Писање и читање се, у светлу оваквих проучавања, сагледавају као културно-историјски детерминисани процеси који и сами повратно делују на стварност која их детерминише. Имајући у виду специфични историјски и друштвени фон збивања који прати објављивање Михаиловићевих дела, критички пријем драме Кад су цзветале тикве пружа могућност за истраживање и сагледавање таквих књижевно-културних релација.

2. НАСТАНАК ДРАМЕ КАД СУ ЦВЕТАЛЕ ТИКВЕ; УПОРЕДНО РАЗМАТРАњЕ РОМАНА И ДРАМЕ. Роман Кад су ц̧ветале тикве, објављен у доба великих политичких комешања 1968. године, био је за то време храбар стваралачки подухват, који је поред своје неоспорне и признате уметничке вредности носио и упечатљиву друштвено-политичку поруку. Ипак, снажан одјек критичке рецепције усмерио се превасходно на високе естетске квалитете које је роман имао да понуди, док је посредни политички ангажман остао ван видокруга тадашњих државних цензора. Велика популарност дела водила је ка новом стваралачком преосмишљавању - уследила је драмска верзија приче о душановачком боксеру, са циљем да се Тикве накнадно изведу и као позоришна представа.

У првим поратним годинама у Југославији културу окупира соцреалистички програм, а уметност подлеже строгој идеолошкој контроли државног врха. Књижевност поприма пропагандни тон, а већина совјетских аутора посвећује своја дела темама социјализма, обнове и прогреса. Овај период Слободан Селенић у Антологији савремене српске драме карактерише следећим речима: „српска послератна драма више од једне деценије не комуницира са идејама и кретањима у драмској литератури других земаља. (...) Потпуно глува за сијасет малих револуција које су потресале драму и театар између два рата, као и за савремена кретања у позоришној мисли (...) српска драма остаје затворена у своје скучене, често полуаматерске, оквире догматског априоризма" (СЕЛЕНИЋ 1977: 18). Око педесетих година двадесетог века на нашим просторима се зачиње идеја о слободи стварања, што је 
водило окретању југословенског стваралаштва према западним културним и уметничким утицајима, и напуштању доташњег совјетског модела, који се одликовао строгом политичком контролом уметничке продукције. Даље стање културне климе праћено је делимичном либерализацијом уметничког израза, који ипак једним делом остаје под контролом скривене политичке цензуре. Драма Кад су ц̧ветале тикве јавља се управо у таквом друштвенополитичком контексту, због чега ће касније бити протумачена и осуђена као прво дело које отворено спомиње тада забрањену тему Голог отока.

О почетним импулсима за настанак драмске верзије романа Михаиловић је говорио у једном од својих интервјуа: „У почетку нисам хтео то да радим. Требало је да драматизацију ради Борислав Михајловић Михиз и представу понуди Народном позоришту. Када је то дошло у Народно позориште, Михиз је одустао јер је имао неке лоше успомене у односу на њега. Наиме, оно је управо тих месеци скинуло с репертоара његову представу Командант Сајлер. Изгледа да је после тога и Народно позориште одустало па је роман дошао до Мире Траиловић у Атеље 212, где је провео извесно време, два, три, четири месеца. (...) Бојан Ступица је најзад успео да ишчупа пројекат од Мире Траиловић и пребаци у Југословенско драмско позориште” (НОВАКОВИЋ 2004: 18). Редитељ Бора Драшковић написао је концепт од првих десетак страница, али је Михаиловић то одбацио и приступио самосталном раду на тексту - тако је настала драма у два чина.

Заједнички наслов романа и драме у извесном смислу потцртава њихову једнакост, иако су околности касније позоришне адаптације, као и измене које су настале транспоновањем наративног језгра у драмски облик, у великој мери одвојиле драму од романа. Трансформација жанра отворила је нове перспективе читања приче и понудила померање значењских нијанси у сегментима који су очигледно одступали од прозне верзије. Ипак, упоредно разматрање обеју верзија Тикава води ка закључку да драма у својој основи не мења значење романа, али га у одређеним аспектима конкретизује, интензивирајући при томе њен политички контекст.

Суштинска разлика драмског и епског књижевног жанра доноси и разлику у обликовању уметничких светова. Драматизацији посебно погодују „она епска дела чије фабуле носе у себи извесну драмску напетост, а уз то су богата дијалозима (...) успелом драматизацијом може се сматрати она која вештим коришћењем свих техничких могућности позоришног језика неупадљиво следи токове оригиналног текста и успева да драмски истакне основну пишчеву замисао" (ЖИВКОВИЋ 1992: 149). У процесу транспоновања романа у драму, драмска форма морала је да разреши најпре разлике жанровске природе - ширину романескне нарације са драмском концизношћу, селективношћу и знаковном јасношћу. Синтетичност драме, као једна од њених диференцијалних карактеристика, нужно води ка принципу сажимања наративног текста, који карактерише сам процес жанровског пре- 
носа. Сажимање треба да обухвати све нивое приче: од фабуле, преко ликова, просторно-временске равни до самог вербалног кода, односно језичког израза. Синтетични драмски израз се тако нашао пред двоструким стваралачки изазовом: он успоставља извесна значења, али истовремено мора да оствари комуникацију са ликовима и гледаоцима. Хијерархија делова и разлика у распореду наративних сегмената такође може изазвати различита нијансирања семантике текста, при чему одређени делови приче могу добити више простора и истакнутију позицију у драмском склопу. Ипак, очување „поретка света” полазног текста у новонасталој драмској верзији зависи од минимума заједничких елемената који оба морају да поседују. Драматизација, дакле, нужно подразумева извесну модификацију значења (која се испољава у већој или мањој мери) и често отвара могућност за неку врсту семантичке надградње полазног текста.

Мали обим романа Кад су и̧ветале тикве погодовао је прилагођавању синтетичној драмској форми. И поред исповести као главне приповедачке форме, драмска верзија није реализована, како би се можда очекивало, у форми монодраме, што би вероватно било и стваралачки најмање захтевно. Михаиловић је, ипак, великом броју ликова дао драмски простор и укључио мноштво дијалошких секвенци, уз инкорпорирање четири монолошке сцене. Двадесет и четири поглавља романа пренесено је у тридесет четири драмске сцене са додатим епилогом на крају.

Тематско и временско померање видљиво је већ у драматизацији почетних догађаја: у роману прича почиње од 1942. године, док драма приказује догађај из 1949. и изоставља седам година Љубиног сазревања. У критици ова чињеница води ка запажању да ,драма престаје да функционише као његова лична прича" (ИЛИЋ 2010: 46), иако се и даље паралелно прате развоји политичког и личног плана дешавања.

Прва сцена у драми приказује силовање и иживљавање Столета Апаше над љубавницом водника Здравка, али је преобликована изостављањем Љубе, који у роману губи невиност силујући немачку келнерицу. У драми се тежиште са лика келнерице помера на лик водника, који Столетовој дружини на почетку прети оружјем користећи моћ униформе. Једина реченица која кореспондира са истом сценом у драми је Столетова реплика коју упућује као претњу келнерици: „Оћеш да кажемо четницима, па да те ошишају?” (МИХАИЛОВИЋ 1994: 27). Оваква места посредно откривају ауторове ставове о комунистичкој власти.

Сукоб Љубе и старог Перишића, који се у роману налази у шестом и седмом поглављу, у драми је обрађен у тринаестој сцени првог чина, која је уједно и најоспораванији део драме. Међу најдужим сценама - скоро тридесетак страница, овде кулминирају експлицитно супротстављена начела драме у односу на роман, чиме долази до померања значења које у први план истиче политичку позадину дела. Интензивиран и психолошки продубљенији сукоб 
између Перишића и Љубе дат је готово симболично - у рингу. Спорна реплика тиче се описа тортуре Удбе, коју у драми изговара Андра, Љубин отац: „Гори су него Немци” (МИХАИОВИЋ 1982: 40), а која је у роману прећутно дата изјавом „Ништа ме не питај (...) Свашта они могу” (МИХИЛОВИЋ 1982: 53). Даљим објашњавањем Владиног положаја, Перишић изговара: „Твога брата на 'Мермер' - знаш ко је отерао?” (МИХАИЛОВИЋ 1983: 44), што представља прво експлицитно спомињање Голог отока у литератури (додуше, у жаргонском облику). Текст драме садржи и информацију о Андрином признању Владине кривице, као илустративан пример тортуре која оца, старог комунисту, наводи на издају сопственог сина. Чак и сцена Андриног симболичног скидања капе пред старим Перишићем сведочи о једном репресивном систему и страху који тадашња власт спроводи над људима. Крајњи сегмент који разоткрива политичке импликације у драми представља дописани део приче, који је у функцији детаљнијег осветљавања Перишићевог лика. У исповедном облику, у току разговора са Ракићем, стари Перишић открива свест о својим „прљавим рукама” и размишља о немогућности бега неумитним силама механизма власти који сатире све пред собом. „Тиме тема власти на филозофском плану добија вишу димензију, а на конкретном политичком плану изражава велику смелост аутора да критику власти прикаже из свести њеног припадника" (ИЛИЋ 2010: 62).

У другом чину драме преко лика народног полицајца Суље приказује се иживљавање и насилништво државног службеника који туче чак и инвалиде. Драмска верзија, међутим, ову сцену додатно политички маркира - у њој се алудира на Титово име, пошто Суља туче Миту Мајмуна јер „нашем маршалу сује мајку рватску" (МИХАИЛОВИЋ 1983: 52). Истом чину Михаиловић је додао и сусрете Душице и Апаша, као и Апаша и Љубе, чиме се појачава мотивација Столетове касније освете. Кроз дописани Драганчетов монолог Љубина судбина и догађаји у његовој породици предочавају се из другачијег угла, са објективније дистанце. Дописани драмски епилог на крају у знаку је тужног резимеа Љубиног живота, дат као нека врста сновиђења. У њему се појављују духови свих страдалих до 1967. године, што драмској целини даје заокружену и уметнички веродостојну поенту. Епилог је у критици протумачен као „функционалан”, иако одступа од рецепата класичне драматургије (ЈАНКОВИЋ 1983: 207).

Сумирану оцену Михаиловићевог драмског рада и поменуте драме даје Петар Марјановић пишући о нашим драмским писцима 20. века: „Драмом Кад су изветале тикве, Михаиловић је доказао да поседује и драмски таленат. (...) Без устручавања ћу (...) рећи да бих већину драматуршких коректних драма наших неокласичних и постмодернистичких драматичара заменио за неколико убедљивих сцена тог дела" (МАРЈАНОВИЋ 1997: 223). Драма Кад су иветале тикве запамћена је као творевина која до данас остаје опомињућа истина о друштву у којем живимо. У стилском и естетском 
смислу, она представља једно од прекретничких дела српске драмске књижевности после Другог светског рата, које својим уметничким вредностима превазилази појам драматизације.

3. РЕЦЕПЦИЈА ДРАМЕ И ЊЕНЕ ПОЗОРИШНЕ АДАПТАЦИЈЕ. Текст драме Кад су цъветале тикве први пут је објављен у Летопису Матице српске, у двоброју за август/септембар 1969. године. Убрзо након тога, заказана је и представа у позоришној дворани Југословенског драмског позоришта. Премијерно извођење представе у режији Боре Драшковића припремано је као велики догађај отварања позоришне сезоне 1969/1970. Поставка представе окупила је око педесетак глумаца, а међу главним улогама нашли су се Михајло Јанкетић, Марко Тодоровић, Миодраг Радовановић, Светлана Бојковић, Михајло Костић, Љубиша Јовановић, Љуба Тадић, Милан Гутовић и други. Представа је постављена у хиперреалистичном проседеу, који је, по речима Александра Новаковића, у то време био веома популаран. Међу иновацијама запажен је и уплив ониричких елемената који описују Љубин боравак у Шведској, као и преписке са познаницима, што је представљало својеврсно одступање од жанра (НОВАКОВИЋ: 2004: 18). Снажне монолошке сцене у драми обогаћене су верним, готово филмским приказима игранке, бокс-мечева и оркестром који је свирао уживо. Матија Бећковић написао је посебно за ову представу Баладу о Љуби Шампиону. И поред велике популарности међу публиком, представа је након петог извођења скинута са репертоара због третмана спорне политичке теме, а овај догађај остао је упамћен као прва цензура власти над позоришном представом у Југославији.

Пре реаговања државног врха и званичне забране представе, први критички одјек изражавао је одушевљење Тиквама - представа је 8. октобра у Политици окарактерисана као „несвакидашњи театарски догађај сезоне”. Жарко Јовановић у чланку „Црни сјај Душановца” за Вечерње новости пише о представи као сценском оживотворењу „најконкретније прозне пулсације у послератној српској књижевности” истичући да се представа „лепи за гледаочево око и срце без остатка" (ЈОВАНОВИЋ 1969: 10). За Политику је 13. октобра писао и Мухарем Первић у чланку „Време прошло, време садашње”. Первић истиче да се драма бави, пре свега, приказом ,угрожене људскости”, и константује споредност политичке теме: „Ако у овој драми нисмо суочени са пуном свестраном политичком истином о Информбироу, то је зато што то и није могуће учинити у оквиру једног уметничког дела, тим пре што овако нешто није ни средишни предмет аутрова дела (...) главни јунак драме непрестано истиче да се он у политику не разуме (...) па се његове изјаве не могу узимати као ауторови погледи" (ПЕРВИЋ 1969: 10). У сличном маниру пише се и у НИН-у: текст „Чари препознавања” указује на чињеницу да се ,збивања на сцени природно надовезују на наше успомене 
у којима је конзервирана слика једног аутентичног амбијента и мирис једне аутентичне атмосфере" (СТАМЕНКОВИЋ 1969: 13).

Ипак, систематско потирање представе креће већ приликом првог извођења - за време паузе примећен је одлазак високог партијског функционеpa, Кире Глигорова, за кога се сматра да је дојавио државном врху информацију о политичкој непримерености комада. Позориштем су се првих неколико дана од премијере шириле гласине о забрани представе, а редитељ Бојан Ступица од стране Градског комитета био је позван на разговор, на који није отишао. Предвиђајући скору забрану представе, у часопису Студент је 14. октобра 1969. године изашла најава дела са подругљивим и упозоравајућим насловом „Брзо погледајте Тикве док није пукла тиква!” Карактеристичан по често ироничном призвуку, часопис се касније нашао на удару тадашње власти, као и Јеж и Книжевне новине. Због све учесталијих напада и притиска режима, чланови Основне организације Савеза комуниста у ЈДП покренули су полемику о представи, расправљајући о њеним најспорнијим деловима и оним сегментима које би требало кориговати. Републичко руководство се и даље није отворено мешало, већ је случај неко време био препуштен Градском комитету и његовим деловањима. Резултат преговора било је избацивање свих непожељних асоцијација и нова верзија представе, у којој су цензурисана сва места која би могла да „изазову неспоразум”. Михаиловић је пристао на скраћивање текста, али не и на дописивање делова.

Један део критичке рецепције драме и представе био је нужно стављен у функцију механизма актуелног напада, па је представа убрзо негативно окарактерисана као свесна политизација позоришта. О томе сведоче и следећи наслови критика: „Политички памфлет с окусом информбировштине”, „Ко с ђаволом Тикве сади (...)”, „Политичко позориште”, „Не цветају само тикве...”, „Слобода која угрожава слободу”, „Где је ждановизам?”2 и слично. О упливу политичке цензуре у сферу публицистичке делатности сведочио је Милош Мишовић, дугогодишњи новинар $H И H$-а, који истиче чињеницу да „идеја о писању таквих чланака готово никада није потицала од редакције” (НОВАКОВИЋ 2004: 30).

Након полемике око забране представе и политичког уплитања између 6. и 12. октобра, уследио је низ оштрих критичких напада на драму и њено позоришно извођење. Међу првима се нашла критика Милосава Мирковића објављена у Политици експрес под насловом „И тиква је воћка чудновата”. Мирковић у тексту критикује аполитичност главног лика као и тему о безразложном хапшењу која представља дисквалификацију историјског чина и историјских акција. У чланку се, такође, отворено апелује на нужност заједничке борбе народа и Партије против Информбироа. Овај напад на представу био је посебно занимљив због чињенице да је исти аутор пет дана раније написао

\footnotetext{
${ }^{2}$ Сви наведени радови објављени су у часопису Сцена, година XXVI, број 2-3, књига 1, мартјун, Нови Сад, 1990.
} 
изразито похвалну реч о представи (НОВАКОВИЋ 2004: 31). Премештањем тежишта рецепције из сфере литерарног у политичку сферу, јављају се напади и у осталим водећим часописима: Борба, Република, Политика, НИН, Комуниста и други. Тадашњи уредник Политике, Драгослав Адамовић, под иницијалима Д. А. тврдио је да представа „није прилог нашој борби против (...) царства мрака, то је - колико знамо - први јавни покушај рехабилитације оних који су се за тај мрак - борили" (АДАМОВИЋ 1990: 95). У НИН-у је поводом представе објављено: „када Тикве од социјалне литературе прерасту у политичко позориште, бар по неким својим детаљима, изневеравајући, при том, принцип истините интерпретације стварности, онда је очигледно да се ради о (...) нездравом делу" (АНОНИМ 1990: 101). Критика анонимног аутора у Комунисту не оспорава представи уметничке домете, али спорну Андрину реченицу из представе „Гори су него Немци” коментарише на следећи начин: „Ни у једној земљи учесници антихитлеровског рата, на истоку или западу, свеједно, не би оставили без оштрог одговора и осуде покушај да се борци против фашизма означавају горим од фашиста" (НОВАКОВИЋ 2004:32). Случај Тикава имао је одјека и у другим републикама: У Vjesniku, у сарајевском Ослобођењу, љубљанској Tedenskoj tribuni и др.

Пресудан моменат за судбину комада била је, наравно, реакција самог државног врха - негативно спомињање представе у говору Јосипа Броза Тита. Наизглед успутно спомињање контроверзне теме приликом говора о пољопривредној потрошњи у Зрењанину, представљало је, заправо, сигнал за забрану приказивања представе и њено скидање са репертоара: „Ево, на пример, недавно сте ви видели, ту неки комад, казалишне неке тиквице. Како цвате тиква, та његова тиква, који је то писао, не цвате, јер она је, изгледа, отпуно гњила и тако даље...где се блати наш друштвени систем (...) А ко говори? Говори онај који је био на Мрамору, на отоку тамо, на Голом отоку (...) Ја не тражим да ми сад њега, шта ја знам, хапсимо, и тако даље, него, напротив, да буде глас јавности, онај који ће њих онемогућити да се баве таквим послом" (НОВАКОВИЋ 2004: 50-51).

Позоришни комад Кад су цвветале тикве је након пет извођења, у истом дану када је Тито одржао говор, скинут с репертоара Југословенског драмског позоришта, а и прозна верзија није прошла без последица - дело Драгослава Михаиловића прогнано је из књижара и библиотека, а последице су сносили и аутори и уметници ангажовани око представе. Рецепција приче о београдском боксеру Љуби Сретеновићу, која отвара тему насиља и политичке тортуре над неистомишљеницима у тадашњој Југославији, попримила је размере политичког скандала. Полемика о Тиквама и разна политичка комешања по Комитету о овој теми означили су зачетак проблематизације слободе говора и изражавања у комунистичком режиму.

Забрана представе вишеструко је узбуркала културну јавност. Петар Марјановић у књизи Српски драмски писции 20. столећа закључује да је „на 
естетском плану био заустављен тек започети ток српске драматургије, у којем се, полазећи од стварног живота (као што су чинили Чехов и други велики писци света у 20. веку), остваривала уверљива уметничка транспозиција" (МАРЈАНОВИЋ 1997: 234). Владета Јанковић коментарише културне последице забране и у њима види опасност доласка стваралачке кризе: „позоришни људи, више од других уметника, пате од недовољног имунитета према вирусу политички мотивисаних забрана. Њих лакше савладавају осећање немоћи, упитаност над смислом сваког, па и сопственог уметничког напора, а извесно и схватљиво самопребацивање због (...) недовољне храбрости" (ЈАНКОВИЋ 1990: 6).

Тикве су поново постављене на сцену тек 1984. године. На Стеријином позорју 1985. представа је, по пишчевим речима, доживела репризу из 1969. године, а критичари су напали ову верзију представе коју је режирала Вида Огњеновић речима попут: „позорје једног ретроградног театра”, „ударац жабокречини београдског позоришног живота" и сл. (НОВАКОВИЋ 2004: 88). Ипак, постојале су и критике које су изразито афирмативно писале о повратку овог драмског комада на сцену. Међу њима је упечатљив текст Авде Мујчиновића у којем се посебно хвали коришћење модерног сценског језика за приказ унутарњег света главног јунака и пратећих догађаја на сцени. По Мујчиновићевим речима, редитељка „демонстрира право мајсторство”, не политизујући текст изван његових оквира (МУЈЧИНОВИЋ 2005: 156). Похвално је о овој поставци писао и Владимир Стаменковић: „Добро је што је Народно позориште (...) понудило најширој публици позориште по њеној мери, али ангажовано и озбиљно, племенито по свом дејству" (СТАМЕНКОВИЋ, 1984). Касније је ово дело извођено и у позориштима у Словенији и Македонији, а 1991. играно је на београдској сцени „Радовић” као монодрама.

4. НОВИЈА ЧИТАњА ДРАМЕ И њЕНИХ АДАПТАЦИЈА. КаДа се МихаиЛовићева књижевна дела и њихова свеукупна критичка рецепција посматрају из данашње перспективе, у знатно другачијим културним и поетичким околностима, отварају се могућности за нов угао читања и тумачења, а самим тим и потреба за ревалоризацијом ствари. Велики удео у задобијању популарности Михаловићевих дела лежи у конкретним културно-историјским струјањима, која их стављају у видокруг целокупне тадашње критичке и културне јавности. Ипак, трајање, актуелност и трансисторијску пријемчивост обезбедили су њихови високи уметнички и литерарни домети. Осим што је српску књижевност свестрано обогатило у готово свим стваралачким аспектима, уметничко дело Драгослава Михаиловића значајно је и у ширем културном смислу. Оно је у великој мери изменило статус свих дотадашњих али и будућих текстова који се баве уметничком транспозицијом ствар- 
ности, и нужно дотичу разне друштвене, историјске и политичке теме. Михаиловић је храбро и међу првима у нашој књижевности крупне теме новије националне историје отргао из мрежа идеолошких тумачења и приказао их у аутентичном виду, с аспекта њиховог погубног деловања на живот појединца или народа. Привлачност Тикава и њихову актуелност у свим временским тренуцима треба потражити у универзалној, готово архетипској причи о човеку у непрестаном сукобу са системом и историјским силама, и последицама које та мукотрпна борба има за људску душу.

Новија читања Михаиловићевих дела, настала у потпуно измењеној друштвеној и културној ситуацији, заузимају другачију перспективу тумачења и евидентно се удаљавају од идеолошки усмерене критике која окупира рецепцију помињаних текстова у претходним годинама. Обновљена свест о естетској суштини и уметничком значају књижевних творевина усмерава рецепцију поменуте драме ка истраживању њених литерарних аспеката и универзалних семантичких матрица којима дело завређује високе уметничке квалитете, са свесним отклоном од идеологије и политичког тумачења. Одређење „политичко позориште”, које је једно време било приписивано Михаиловићевој драми, почиње да се сматра погрдним и штетним jep „замагљује и друштвену и естетску суштину навиталнијег тока нашег данашњег позоришта” које „(...) поред политичког има и широку лепезу других аспеката, почев од поетског, преко антрополошког, до метафизичког (...)" (СТАМЕНКОВИЋ 2000: 66). У књизи објављеној 1997. године Петар Марјановић у тексту „Носталгични осветник с периферије града” анализира садржај и структуру Тикава, остављајући у сенци политичку и историјску позадину дела. Фокус се у Марјановићевом тумачењу премешта на структурне одлике драме, које се сагледавају у спрези са значењским дометима и психологијом лика коју писац жели да прикаже. Такође, у тексту се истражује структура сценског збивања у Тиквама, са посебним освртом на технике отворене и затворене драмске форме, које писац користи у обликовању овог дела (МАРЈАНОВИЋ 1997: 223-235).

Од новијих критика које се баве Тиквама, процес трансформације романа у драму најпотпуније анализира студија Марије Илић у књизи Исто и друго. Упоредним разматрањем прозне и драмске верзије, М. Илић истражује пренос почетне слике света, као и извесне модификације значења дела настале његовом жанровском трансформацијом. Поредбеном релацијом између драме и романа у тексту се указује на конкретизације одређених места у драми, које директно интензивирају политички контекст дела. Ауторка у њима види повод за другачији жанровски третман ових текстова у јавности, будући да прозна верзија није претрпела никакве забране када се појавила, иако се подједнако супротставља прокламацијама тадашње идеологије (ИЛИЋ 2010: 44-69). Драматизацијом романа бави се и студија Јелене Перић, објављена у Театрону 2013. године. Пошавши од усклађености драме 
и Аристотелових поетичких принципа у трагедијама, А. Перић констатује да би се „Михаиловић (...) готово идеално уклопио у Аристотелове представе о односу радње, карактера и мисли у трагедији” (ПЕРИЋ 2013: 127). Даља разматрања у тексту тичу се трагичног потенцијала самог лика Љубе Шампиона, кога ауторка посматра у контексту теорије Нортропа Фраја, смештајући га у домен Фрајевог лика фармакоса. Један део студије посвећен је и анализи политички маркираних ликова, истраживању природе конфронтација које се јављају у радњи, као и приказу најбитнијих јунака понаособ (ПЕРИЋ 2013: 125-135).

Даља критичка читања која се баве овом драмом обележена су појавом најновије позоришне адаптације Тикава из 2014. године, коју је режирао Бобан Скерлић. Представа је изведена је у Београдском драмском позоришту, а непосредно након извођења покупила је бројне похвалне критике. Појавом ове театарске поставке евидентан је заокрет у рецепцији Тикава: од оних који се фокусирају на саму драму, ка позоришној критици која се бави анализом Скерлићеве режије. Критички текстови углавном истражују меру у којој најновија адаптација успева да сачува аутентичну причу Tикава, а да је истовремено представи у новом, модернијем руху. Ана Тасић у чланку под називом „Свеж дах у позоришту” у Политици пише: „Редитељ је Михаиловићев текст поставио монументално, реалистички, суптилно додајући есенцијалне поетске зачине. (...) Захваљујући вишезначности Михаиловићевог опоро реалистичког, готово бруталистичког комада, чињенице да он садржи зреле политичке, социјалне, мелодрамске, као и поетске нивое значења, представа Кад су и̧ветале тикве Београдског драмског позоришта је успела да донесе мноштво и данас актуелних, савремених и универзалних тема" (ТАСИЋ 2014). А. Тасић даље константује пренос тематског фокуса на индивидуално-породична питања комада, док политички интонирани делови фигурирају у позадини као „ехо наше табу прошлости”. Ауторка похвално говори и о поетским наносима у представи, који са једне стране ублажавају бруталност приче, али и обогаћују основну поставку догађаја.

Коментар представе изведене у Београдском драмском позоришту дала је и Маша Стокић са акцентом на драмски третман универзалне приче о границама људског морала. Текст даје осврт на одлично изведени приказ деградације младог човека који под притиском система не успева да остане „чистих руку”, као и морално и физичко урушавање породице у сплету сурових социјално-политичких превирања (СТОКИЋ 2014). Поред афирмативних критика, чланак Златка Паковића „Без ризика мишљења” у листу Данас скреће пажњу на оно што су, по ауторовом мишљењу, недостаци Скерлићеве режије. Паковић образлаже да представа са таквим контроверзним одјеком у прошлости на одређени начин обавезује будуће ствараоце, и да Скерлић у својој режији пренебрегава чињеницу да је ,„озоришна режија мишљење у драмској акцији, односно да је у њој сваки естетски чин и социјални чин par 
excellence". Посматрајући је из тог угла, најновија адаптација Тикава у Паковићевом тумачењу забрањује себи ,постављање питања” и лишена било каквог стваралачког ризика, остаје ,пуко аранжирање позоришних сцена из Михаиловићевог комада" (ПАКОВИЋ 2014).

Савремени критички одјек Михаиловићеве драме и њених адаптација приметно је мањег обима од оног који је дело имало у тренутку појављивања и време првих позоришних поставки. Иако је већина актуелне рецепције усмерена на позоришно извођење драме, свака од тих критика се барем једним својим делом осврће на изворну причу Тикава и значај овог комада за српску књижевност и наш национални театар. Посматрајући Tuкве у ширем контексту наше драмске и позоришне уметности Петар Волк говори о њиховом општем значају и позицији: „Једноставно, позориште је извођењем Михајловићевог комада прешло ону дозвољену границу до које се осећају обавезе и дужности у вези саме политике. То је заправо био вапај за слободом и сасвим новим односом према животу. Истовремено, тиме је одбачена нетолеранција, неодговорност према човеку, лажно веровање и самообмана" (ВОЛК 1995). Упркос тортури којој његово књижевно дело бива изложено претходних година, Михаиловића негативан критички одјек не спречава да у наредним годинама голоотачкој теми посвети велики део свог опуса и настави да је стваралачки обрађује у другим књигама.

С обзиром на чињеницу да некада спорни делови Михаиловићеве драме у данашњим околностима имају другачији референцијални домен, политички контекст који је преводио некадашњу критичку рецепцију на идеолошки хоризонт тумачења данас се издиже на универзални ниво. Драма се све више тумачи изван национално обојених значења, а приказ комунистичке тортуре функционише као модел мноштва могућих репресивних политичких система који деструктивно делују на човека и цивилизацију уопште. Та чињеница, као и третман других општих и архетипских тема којима се драма бави, обезбеђују јој актуелност и могућност сталне стваралачке обнове која отвара нове углове читања. Померање ка универзално-људском и ка естетској сржи драме видљиво је и у савременим критичким одговорима, а директиву за овакво тумачење даће и сам писац у интервјуима: „Живот у књижевности доста је клизав, може се десити да један интересантан текст изгуби свежину и човек се нађе на ледини. Ово није текст само с политичким значењем: говори о људима и људским судбинама" (МИХАИЛОВИЋ 2013).

Рецепција Михаиловиће драме у овом раду представљена је и промишљена из културолошке перспективе, са увидом у њено свеукупно егзистирање кроз историју и утицаје који су условили различите валоризације у критичком одговору од објављивања до данас. Догађај у вези са забраном Тикава сматра се једном од преломних тачака у историји српске културе 20. века, која иницира отпор према забранама и идеолошким притисцима, почевши отпором према диктату Комунистичке партије. Иако је критичка рецепција знатно обимнија у 
случају романа, драма и представа остају запамћени као директни субверзивни акт који је подривао тадашњи друштвено-политички систем, истовремено отварајући пут новим уметничким слободама стварања, говора и мишљења.

\section{Цитирана литература}

АДАМОВИЋ, Драгослав. „Не цветају само тикве...”. Сцена, година XXVI, број 2-3, књига 1, март-јун, Нови Сад, 1990.

ВОЛК, Петар. Писии националног театра. <https://www.rastko.rs/drama/pvolkpisci/pvolk-pisci.html\#_Toc2131713> 6.2.2018.

ДАНОЈЛИЋ, Милан. „Страдање Љубе Шампиона”. Борба, 28. 12. 1968.

ИЛИЋ, Марија. „Трансформација романа Кад су ияветале тикве”. Исто и друго, Београд: Алтера, 2010.

ЈАНКОВИЋ, Владета. „О драмама Драгослава Михаиловића”. поговор у: Драгослав Михаиловић.Увођење у посао, Београд, 1983.

ЈОВАНОВИЋ, Жарко. „Црни сјај Душановца”. Вечерње новости, 8. 10. 1969.

МАРЈАНОВИЋ, Петар. Српски драмски писии 20. столећа. Матица српска, Нови Сад, 1997.

МИХАИЛОВИЋ, Драгослав. „Кад су цветали страхови и лажи”. Вечерње новости. $\quad<$ http://www.novosti.rs/\%D0\%B2\%D0\%B5\%D1\%81\%D1\%82\%D0\% B8/\%D0\%BA\%D1\%83\%D0\%BB\%D1\%82\%D1\%83\%D1\%80\%D0\%B0.487. html:459095-Dragoslav-Mihailovic-Kad-su-cvetali-strahovi-i-lazi> 6. 2. 2018.

МУЈЧИНОВИЋ, Авдо. „Узбудљиво до суза и смеха”. Позоришне критике, Стеријино позорје, Нови Сад, 2005.

НОВАКОВИЋ, Александар. Како је Тито разбијао тикве. Београд: Народна књига, 2004.

ПАКОВИЋ, Златко. „Без ризика мишљења”. <https://www.danas.rs/kultura/bezrizika-misljenja/> 6. 2. 2018.

ПЕРВИЋ, Мухарем. „Време прошло, време садашње”. Политика, 13. 10. 1969.

ПЕРИЋ, Јелена. „Кад су цветале тикве - драма”. Театрон, број 164/165, година XXXVII, Београд, 2013.

СЕЛЕНИЋ, Слободан. Антологија савремене српске драме. Београд, 1977.

СТАМЕНКОВИЋ, Владимир. „Чари препознавања”. НИН, 12. 10. 1969.

СТАМЕНКОВИЋ, Владимир. „Позориште и коначно решење”. Крај утопије и позориште. Критике и есеји (1985-2000). Београд: Откровење, Нови Сад: Стеријино позорје, 2000.

СТОКИЋ, Маша. „Кад су цветале тикве”. < http://www.bdp.rs/index.php/predstave/ kad-su-cvetale-tikve> 6. 2. 2018.

ТАСИЋ, Ана. „Свеж дах у позоришту”. Политика. <http://www.politika.rs/scc/ clanak/294367/Svez-dah-u-pozoristu> 6. 2. 2018. 


\section{Извори}

МИХАИЛОВИЋ, Драгослав. Кад су иветале тикве. Београд, 1993.

МИХАИЛОВИЋ, Драгослав. Увођење у посао. Београд: Народна књига, 1983.

Hristina Aksentijević

\section{„WHEN THE PUMPKINS BLOOMED” - PLAY AND THEATRE PERFORMANCES IN HISTORY OF RECEPTION}

The paper is concerned with the reception of Mihailovićs play When the pumpkins bloomed and how it is perceived in relation to social-historical context and political background which follows its publishing and theatre performances. The critique reception of the novel is linked to the altogether cultural-historical dialogue of the reader and the text, with emphasising the influence of the external circumstances to the forming of the individual and collective reading experiences, as well as the different interpretations and evaluation of the mentioned text. The paper gives an overview of the specific "artistic existence" of the Pumpkins' play version, with a turn to a much wider cultural context and a divided critique of different interpretations of the play, which are responsible for the controversial status Mihailović's works have even in the present time.

Keywords: dramatization, reception, cultural-historic context, theatre performance, subversiveness, critique. 